\title{
$\beta$-Thalassemia mutations and hemoglobinopathies in Adana, Turkey: results from a single center study
}

Birol Guvenc ${ }^{1-3}$, Abdullah Canataroglu $u^{4}$, Cagatay Unsal', Sule Menziletoglu Yildiz ${ }^{5}$, Ferda Tekin Turhan ${ }^{2}$, Sevcan Tug Bozdogan ${ }^{3}$, Suleyman Dincer ${ }^{6}$, Hakan Erkman ${ }^{3}$

${ }^{1}$ Department of Hematology, Faculty of Medicine, Cukurova University, Adana, Turkey ${ }^{2}$ Hemapheresis, Stem Cell and Cryopreservation Unit, Cukurova University, Balcali Hospital, Adana, Turkey

3Seyhan Hereditary Blood Disorders Center, Adana, Turkey

${ }^{4}$ Adana Numune Training and Research Hospital, Adana, Turkey

${ }^{5}$ Health Services Vocational School, Cukurova University, Adana, Turkey

${ }^{6}$ Department of Hematology, Faculty of Medicine, Yeditepe University, Istanbul, Turkey

Submitted: 15 October 2010

Accepted: 9 June 2011

Arch Med Sci 2012; 8, 3: 411-414

DOI: 10.5114/aoms.2012.28811

Copyright $\odot 2012$ Termedia \& Banach

\begin{abstract}
Introduction: $\beta$-Thalassemia and hemoglobinopathies are common genetic disorders in Turkey and in this retrospective study our aim was to determine the frequency of $\beta$-thalassemia and hemoglobinopathies in Adana, which is one of the biggest cities located in the southern part of Turkey.

Material and methods: Data from 3000 individuals admitted to Seyhan Hereditary Blood Disorders Center in Adana were evaluated. The blood samples were collected into EDTA-containing tubes and hematological parameters were analyzed using an automatic cell counter. High performance liquid chromatography technique was used to determine the type of hemoglobin. Molecular screening of the $\beta$-globin gene was performed with $\beta$-Globin StripAssay.

Results: Of 3000 cases, 609 were diagnosed as $\beta$-thalassemia or hemoglobinopathy. We have found that the rates of occurrence of $\beta$-thalassemia and hemoglobinopathies are $13.46 \%$ and $6.83 \%$ respectively in this area. We have identified 18 different $\beta$-thalassemia mutations and three separate abnormal hemoglobins: $\mathrm{HbS}, \mathrm{HbD}$ Los Angeles, and $\mathrm{HbE}$. In molecular analyses, $\beta$-thalassemia gene mutations of IVSI.110 (G>A), codon $8(-A A)$, IVSI.1 (G>A), IVSI.6 $(T>C),-30(T>A)$, IVSII.1 $(G>A)$, codon $39(C>T)$, codon $44(-C)$, IVSI.5 $(G>C)$, codon $5(-\mathrm{CT})$, codon 8/9 $(+\mathrm{G})$, IVSII.745 $(\mathrm{C}>\mathrm{G})$, codon 22 (7bp del), $-101(\mathrm{C}>\mathrm{T})$, codon $36 / 37(-T)$, IVSI.15 $(T>G)$, codon $6(-A),-88(G>A)$ were detected.

Conclusions: Considering the high incidence of mutations that we have found, $\beta$-thalassemia and hemoglobinopathies still seem to be a public health problem in Adana.
\end{abstract}

Key words: $\beta$-Globin StripAssay, $\beta$-thalassemia, hemoglobinopathy, mutation, sickle cell anemia.

\section{Introduction}

$\beta$-Thalassemia ( $\beta$-thal) syndromes, among the most common hereditary diseases worldwide, are characterized by a genetic deficiency in the synthesis of $\beta$-globin chains [1]. The $\beta$-thal results from mutations that cause reduced ( $\beta^{+}$type) or absent $\left(\beta^{\circ}\right.$ type) $\beta$-globin chain synthesis [2]. A total of 393 thalassemia mutations have been reported so far [3].

\section{Corresponding author:}

Assoc. Prof. Dr. Birol Guvenc Department of Hematology

Faculty of Medicine

University of Cukurova

01330, Balcali

Adana, Turkey Phone: +90 (322) 338 6060/3141 Fax: +90 (322) 3386938 E-mail: guvenc.birol@gmail.com, guvenc.birol@cu.edu.tr 
Hemoglobinopathy is a genetic defect that results in abnormal structure of one of the globin chains of the hemoglobin molecule [4]. Hemoglobin $\mathrm{S}$ (HbS, $\beta 6 \mathrm{Glu}-\mathrm{Val})$ results from a single base mutation in the $\beta$-globin gene, and is the most prevalent abnormal hemoglobin in Turkey [5]. It has been reported that Hemoglobin D ( $\beta 121 \mathrm{Glu}-\mathrm{Gln})$ is the second most common hemoglobinopathy in Turkey and is distinguished from HbS by its normal solubility and its failure to produce sickling in a deoxygenated state. Hemoglobin E ( 326 Glu-Lys), the third most commonly seen abnormal hemoglobin in Turkey, is a thalassemic hemoglobinopathy characterized by microcytosis and hypochromia [5-7].

The $\beta$-thal is widespread throughout the Mediterranean Region, in Africa, the Middle East, the Indian subcontinent and Burma, Southeast Asia and Indonesia [8]. Similarly, hemoglobinopathies are common in different ethnic groups and in a broad geographic area including Equatorial Africa, Southern Turkey, Saudi Arabia, Southern India, and Greece [1, 2].

Adana, which is the biggest city located in the Cukurova Region in the southern part of Turkey, has been shown to be one of the top cities in terms of the frequency of $\beta$-thal and hemoglobinopathies. Mersin and Antakya, two other cities located in the Cukurova Region, also have a high rate of $\beta$-thal and hemoglobinopathies. Following Aksoy et al.,

Table I. Frequencies of $\beta$-thalassemia mutations in Adana

\begin{tabular}{|llcc|}
\hline Mutation & Type & No. of cases & Percentage \\
\hline IVSI.110 (G>A) & $\beta^{+}$ & 142 & 35.14 \\
\hline Codon 8 (-AA) & $\beta^{0}$ & 37 & 9.15 \\
\hline IVSI.1 (G>A) & $\beta^{0}$ & 35 & 8.66 \\
\hline IVSI.6 (T>C) & $\beta^{+}$ & 31 & 7.67 \\
\hline -30 (T>A) & $\beta^{+}$ & 30 & 7.42 \\
\hline IVSII.1 (G>A) & $\beta^{0}$ & 26 & 6.43 \\
\hline Codon 39 (C>T) & $\beta^{0}$ & 24 & 5.94 \\
\hline Codon 44 (-C) & $\beta^{0}$ & 20 & 4.95 \\
\hline IVSI.5 (G>C) & $\beta^{+}$ & 15 & 3.71 \\
\hline Codon 5 (-CT) & $\beta^{0}$ & 12 & 2.97 \\
\hline Codon 8/9 (+G) & $\beta^{0}$ & 10 & 2.47 \\
\hline IVSII.745 (C>G) & $\beta^{+}$ & 9 & 2.22 \\
\hline Codon 22 (7bp del.) & $\beta^{0}$ & 4 & 0.99 \\
\hline -101 (C>T) & $\beta^{+}$ & 3 & 0.74 \\
\hline Codon 36/37 (-T) & $\beta^{0}$ & 3 & 0.74 \\
\hline IVSI.116 (T>G) & $\beta^{0}$ & 1 & 0.25 \\
\hline Codon 6 (-A) & $\beta^{0}$ & 1 & 0.25 \\
\hline -88 $(G>A)$ & $\beta^{+}$ & 1 & 100 \\
\hline Total & & 404 & \\
\hline
\end{tabular}

who initiated scientific investigations on abnormal hemoglobins in Turkey in 1955, data from several studies have been published and the prevalence of sickle cell trait ( $\mathrm{Hb}$ AS) has been found to be $8.2 \%$ in the Cukurova Region $[9,10]$. The rate of occurrence of $\beta$-thal has been reported to be approximately $4.3 \%$ in Turkey [11]. However, in some parts, the rate increases to as high as $10 \%$ to $13 \%[8,11]$.

In this retrospective study, we report the number and the type of $\beta$-thal mutations and hemoglobinopathies detected in individuals admitted to Seyhan Hereditary Blood Disorders Center (SHBDC) in Adana with a complaint of anemia. Molecular analysis of the $\beta$-globin gene was performed using a $\beta$-Globin StripAssay. We have identified 18 different $\beta$-thal mutations and three different abnormal hemoglobins: HbS, HbD Los Angeles, and $\mathrm{HbE}$.

\section{Material and methods}

Data from 3000 individuals, including premarital couples and patients with symptoms of anemia, admitted to SHBDC were restrospectively analyzed. Of these cases, 609 were found to be diagnosed as $\beta$-thal or hemoglobinopathy.

Blood samples were collected in EDTA containing tubes and high performance liquid chromatography (HPLC) technique was used to confirm the diagnosis. To perform molecular diagnostic tests, DNAs were isolated from white blood cells by using conventional methods. Mutation analyses for the $\beta$-globin gene were evaluated with $\beta$-Globin StripAssay (ViennaLab cat. no. 4-120, Austria), which is used for detection of the 22 most common $\beta$-thalassemia and hemoglobinopathy mutations in the Mediterranean Region. The StripAssay is based on the reverse-hybridization technique. The $\beta$-globin genes of isolated DNAs are amplified in vitro by multiplex PCR and labeled with biotin in a single reaction. Subsequently, the amplification products are hybridized to oligonucleotide probes (wild and mutant type) containing the test strip.

Approval from the institutional Ethics Committee of Seyhan Hereditary Blood Disorders Center was provided for this study.

\section{Results}

DNA samples from 609 individuals with $\beta$-thal or hemoglobinopathies were analyzed and 18 different $\beta$-thal mutations and also HbS, HbD Los Angeles, and $\mathrm{HbE}$ were identified. Molecular features of the patients are detailed in Tables I-III.

The most frequent mutation of $\beta$-thal was found to be IVSI.110 (G>A) in Adana followed by codon 8 $(-A A)$, IVSI.1 (G>A), IVSI.6 (T>C), -30 (T>A), IVSII.1 $(\mathrm{G}>\mathrm{A})$, codon $39(\mathrm{C}>\mathrm{T})$, codon $44(-\mathrm{C})$, IVSI.5 $(\mathrm{G}>\mathrm{C})$, codon $5(-\mathrm{CT})$, codon 8/9 $(+\mathrm{G})$, IVSII.745 $(\mathrm{C}>\mathrm{G})$, codon 22 (7bp del), -101 (C>T), codon 36/37 (-T), 
Table II. Frequency of hemoglobinopathy mutations in Adana

\begin{tabular}{|lccc|}
\hline Mutation & Type & No. of cases & Percentage \\
\hline HbS & $\beta^{S}$ & 192 & 93.65 \\
\hline HbD Los Angeles & $\beta^{D}$ & 7 & 3.42 \\
\hline HbE & $\beta^{\mathrm{E}}$ & 6 & 2.93 \\
\hline Total & & 205 & 100 \\
\hline
\end{tabular}

IVSI.15 $(\mathrm{T}>\mathrm{G})$, codon $6(-\mathrm{A})$, and $-88(\mathrm{G}>\mathrm{A})$ respectively (Table I). The overall rate of occurrence of $\beta$-thal mutations in our group was $13.46 \%(n=404)$.

We detected 205 cases with abnormal hemoglobins out of 3000 individuals (6.83\%). One hundred and ninety-two of 205 subjects with abnormal hemoglobins were heterozygous $\mathrm{HbS}$ (93.65\%) whereas seven and six of these subjects were identified as HbD Los Angeles (3.42\%) and HbE (2.93\%) respectively (Table II). Therefore, the frequency of $\mathrm{HbS}$ heterozygotes among 3000 subjects admitted to our center was found to be $6.4 \%$. The frequency of $\mathrm{HbD}$ Los Angeles and $\mathrm{HbE}$ in the whole group was $0.23 \%$ and $0.2 \%$ respectively.

There were a total of 56 cases who were either homozygous or compound heterozygous amongst our subjects. While 40 of 56 cases were diagnosed as sickle cell homozygotes (71.43\%), 10 cases were $\beta$-thal major (17.87\%), 5 cases were compound heterozygotes (8.93\%) and 1 subject was $\mathrm{HbS} / \mathrm{HbD}$ (1.79\%) (Table III). In summary, the rate of sickle cell homozygote cases among our group was $1.33 \%$.

\section{Discussion}

The $\beta$-thals were among the first human genetic diseases to be analyzed by recombinant DNA technology. Today, the molecular pathology of disorders resulting from mutations in the $\beta$-globin gene region has been well defined, and point mutations have been found to be the main cause of molecular defects in $\beta$-thals $[12,13]$. Adana is one of the oldest settlements in Turkey. The first settlers arrived in this region during the Paleolithic period, that is at least 3000 years ago. Since then, Arab, Byzantine, Sumerian, Hittite and Turkish societies have lived here and played important roles in the history of the region, subsequently leading to a complex ethnic structure.

Currently the majority of the population in Adana is of Arab origin, known as "Eti-Turks", whose ancestors immigrated from Syria and Egypt centuries ago. Antakya and Mersin are neighbor cities of Adana and most of the people who live there are also of Arab origin. Therefore, the prevalence of $\mathrm{HbS}$ has been found to be considerably high in these areas compared to other parts of Turkey. In addition, consanguineous marriages are seen in a high incidence in these provinces, which also contributes
Table III. The number and percentage of homozygous and compound heterozygous genotypes in Adana

\begin{tabular}{|lcc|}
\hline Genotype & Number & Percentage \\
\hline HbS/HbS & 40 & 71.43 \\
\hline IVSI.110/HbS & 4 & 7.14 \\
\hline IVSI.6/IVSI.6 & 3 & 5.36 \\
\hline IVSII.1/IVSII.1 & 2 & 3.57 \\
\hline$-30 /$ IVSI.6 & 2 & 3.57 \\
\hline Codon 8/HbS & 1 & 1.79 \\
\hline IVSI.1/IVSI.1 & 1 & 1.79 \\
\hline -30/-30 & 1 & 1.79 \\
\hline IVSI.110/IVSI.110 & 1 & 1.79 \\
\hline HbS/HbD Los Angeles & 1 & 1.79 \\
\hline Total & 56 & 100 \\
\hline
\end{tabular}

to the increased frequency of $\mathrm{HbS}$ and $\mathrm{HbE}$ heterozygotes [14, 15].

Aksoy reported the first case with $\mathrm{HbS}$ trait in Southern Turkey in 1955 [9]. The first study regarding $\beta$-thal was also published by Aksoy et al. in 1985 [16]. The prevalence of $\beta$-thals varies greatly between different parts of Turkey, however; the overall percentage has been reported to be $4.3 \%$ $[8,11,17,18]$. A screening study conducted by Yüregir et al. revealed that the incidences of $\beta$-thals and $\mathrm{HbS}$ trait were $3.7 \%$ and $8.2 \%$ respectively in the Cukurova Region [15].

In our study, we performed a screening program mostly for premarital couples at SHBDC to determine the frequency of $\beta$-thal and hemoglobinopathies in Adana. We have detected a total of 609 cases with $\beta$-thal or hemoglobinopathies. Abnormal hemoglobins consisting of $\mathrm{HbS}$ trait in 192 samples (6.4\%), 7 of $\mathrm{HbD}$ Los Angeles $(0.23 \%)$ and 6 of $\mathrm{HbE}(0.2 \%)$ and 404 patients with heterozygote thalassemia (13.46\%) were found. Although the rate of occurrence of $\mathrm{HbS}$ trait that we found is consistent with previous studies, the prevalence of $\beta$-thal reported in our study is higher than the results revealed from other studies $[6,7]$. Since the SHBDC solely focuses on performing molecular analysis on $\beta$-thal and abnormal hemoglobins in Adana, our study population consists of individuals with a family history or high risk of $\beta$-thal and hemoglobinopathies. Thus, the high rate of $\beta$-thals should not be considered contradictory with previous studies $[7,19]$.

In Adana, we have identified 18 different $\beta$-thal mutations in 404 cases, whereas Altay and Tadmouri reported more than 30 mutations of the globin gene in Turkey $[8,17]$. The nine most prevalent $\beta$-thal mutations were noted in $89 \%$ of our cases (Table I). These results confirm that $\beta$-thal mutations are highly heterogeneous, attributed to the ethnic characteristics in different parts of Turkey. 
In our study, we have found that the most common $\beta$-thal mutation is IVSI.110 (G>A), similar to the data published by Altay [8]. IVSI.110 (G>A) mutation was identified in 142 cases (35.14\%) in our cohort, which appears to be related to consanguineous marriages in Adana. We noted that codon 8 mutation, which is present at high frequencies in Azerbaijan [20], is the second most commonly seen defect of $\beta$-thal in Adana. This result is found to be different from two large studies performed by and Bașak et al. [17, 18]. The mutations of -30 and codon 39, commonly encountered in Balkan countries [ $4,21,22]$, showed rates of $7.48 \%$ and $5.98 \%$ respectively in this study.

Although $\mathrm{HbE}$ is the second most common hemoglobinopathy worldwide, $\mathrm{HbD}$ Los Angeles has been reported to be the second most prevalent abnormal hemoglobin seen among Eti-Turks, with a frequency of $0.16-2.4 \%$ in our country [23]. Our results with $0.23 \%$ of $\mathrm{HbD}$ Los Angeles are consistent with those of Güler et al. [24].

In conclusion, a variety of PCR-based methods are currently in use for detection of the most common $\beta$-thal mutations. We have observed that $\beta$-Globin StripAssay provides a simple, rapid and sensitive method to identify $\beta$-thal mutations and hemoglobinopathies even in large numbers of cases for screening programs.

Although the Deniz Database in Bogazici University has been used to collect data regarding $\beta$-thal mutations from different countries, a national database needs to be established in order to compose a map of the $\beta$-globin gene in our country.

Our results indicate that $\beta$-thal and hemoglobinopathies still appear to be an important public health problem in Adana. Due to the fact that consanguineous marriages are very common in this area, genetic counseling should be provided for premarital couples to prevent homozygote births.

\section{References}

1. Lukens JN. The thalassemias and related disorders: quantitative disorders of hemoglobin synthesis. In: Wintrobe's Clinical Hematology. 10 ${ }^{\text {th }}$ ed. Egypt: Mass Publishing; 1999. p. 1405-48.

2. Weatherall DJ, Clegg JB, Higgs DR, Wood WG. The Hemoglobinopathies. In: Scriver CR, Beaudet A, Sly WS, Valle D, editors. The metabolic and molecular bases of inherited disease. New York: McGraw-Hill; 1989. p. 3417-83.

3. http://globin.bx.psu.edu/cgi-bin/hbvar/counter

4. Efremov GD. Thalassemias and other hemoglobinopathies in Former Yugoslavia. BJMG 2008; 11: 11-26.

5. Altay Ç. Abnormal Hemoglobins in Turkey. Turk J Haematol 2002; 19: 63-74.

6. Kılınç Y. Hemoglobinopathies in Turkey. Turk J Hematol 2006; 23: 214-16.

7. Tosun F, Bilgin A, Kızılok A, Arpacı A, Güneș T, Yüregir GT. Five year evaluation of premarital screening program for hemoglobinopathies in province of Mersin, Turkey. Turk J Hematol 2006; 23: 84-9.
8. Altay C. The frequency and distribution pattern of $\beta$-thalassemia mutations in Turkey. Turkish J Hematol 2002; 19: 309-15.

9. Aksoy M. Sickle-cell trait in South Turkey. Lancet 1955; 268: 589-90.

10. Cürük MA, Zeren F, Genç A, Ozavci-Aygün S, Kilinç Y, Aksoy K. Prenatal diagnosis of sickle cell anemia and betathalassemia in southern Turkey. Hemoglobin 2008; 32: 525-30.

11. Acemoglu H, Beyhun NE, Vancelik S, Polat H, Guraksin A. Thalassaemia screening in a non-prevalent region of a prevalent country (Turkey): is it necessary? Public Health 2008; 122: 620-4.

12. Pereira Mdel M, Dalmau AC, Corrons JL. Molecular heterogeneity of beta-thalassemia alleles in Spain and its importance in the diagnosis and prevention of beta-thalassemia major and sickle cell disorders. Hemoglobin 2009; 33: 226-34.

13. Lotfi M, Keramati P, Assdsangabi R, Nabavizadeh SA, Karimi M. Ultrasonographic assessment of the prevalence of cholelithiasis and biliary sludge in beta-thalassemia patients in Iran. Med Sci Monit 2009; 15: 398-402.

14. Altay C, Basak AN. Molecular basis and prenatal diagnosis of hemoglobinopathies in Turkey. Int J Pediatr Hematol Oncol 1995; 2: 283-90.

15. Yüregir GT, Donma O, Dikmen N, Isbir T, Cinar M. Population studies of hemoglobin $\mathrm{S}$ and other variants in Cukurova, the southern part of Turkey. Nippon Ketsueki Gakkai Zasshi 1987; 50: 757-65.

16. Aksoy M, Kutlar A, Kutlar F, Dinçol G, Erdem S, Baștesbihçi S. Survey on haemoglobin variants, beta thalassaemia, glucose-6-phosphate dehydrogenase deficiency, and haptoglobin types in Turks from western Thrace. J Med Genet 1985; 22: 288-90.

17. Tadmouri GO, Bașak AN. Beta-thalassemia in Turkey: a review of the clinical, epidemiological, molecular, and evolutionary aspects. Hemoglobin 2001; 25: 227-39.

18. Bașak AN. The molecular pathology of beta-thalassemia in Turkey: the Bogaziçi University experience. Hemoglobin 2007; 31: 233-41.

19. Cürük MA, Arpaci A, Attila G, et al. Genetic heterogeneity of beta-thalassemia at Cukurova in southern Turkey. Hemoglobin 2001; 25: 241-5.

20. Kuliev AM, Rasulov IM, Dadasheva T, et al. Thalassaemia in Azerbaijan. J Med Genet 1994; 31: 209-12.

21. Georgiou I, Makis A, Chaidos A, et al. Distribution and frequency of beta-thalassemia mutations in northwestern and central Greece. Eur J Haematol 2003; 70: 75-8.

22. Efremov GD. Thalassemias and other hemoglobinopathies in the Republic of Macedonia. Hemoglobin 2007; 31: 1-15.

23. Akar E, Akar N. A review of abnormal hemoglobins in Turkey. Turk J Hematol 2007; 24: 143-45.

24. Güler E, Çelik M, Davutoglu M, Ekerbiçer HÇ, Karabiber $H$. The evaluation of results of the premarital screening of hemoglobinopathies trait in Kahramanmaras. TAF Prev Med Bull 2008; 7: 243-4. 